\title{
Curcumin Therapy in Inflammatory Bowel Disease: A Pilot Study
}

\author{
PETER R. HOLT, MD, ${ }^{*}$ SEYMOUR KATZ, MD,$\dagger$ and ROBERT KIRSHOFF†
}

\begin{abstract}
Curcumin, a natural compound used as a food additive, has been shown to have anti-inflammatory and antioxidant properties in cell culture and animal studies. A pure curcumin preparation was administered in an open label study to five patients with ulcerative proctitis and five with Crohn's disease. All proctitis patients improved, with reductions in concomitant medications in four, and four of five Crohn's disease patients had lowered CDAI scores and sedimentation rates. This encouraging pilot study suggests the need for double-blind placebo-controlled follow-up studies.
\end{abstract}

KEY WORDS: curcumin; ulcerative proctitis; Crohn's disease; inflammatory bowel disease.

Curcumin is a natural compound found in the plant $\mathrm{Cur}$ cuma longa which is used as a food additive known as turmeric. The major pigment in turmeric is curcumin (chemical name diferuloymethane), which possesses both anti-inflammatory $(1,2)$ and antioxidant properties $(3,4)$ Topical application of curcumin inhibits carcinogeninduced DMA adduct formation and the development of skin tumors. Curcumin also strongly inhibits proliferation of HT-29 and HCT-15 human colon cancer cell lines (5). Dietary administration of curcumin suppresses the development of chemically induced cancers. These properties have led to studies of the chemopreventive effects of curcumin which also showed that the agent reduces colonic inflammatory responses (6). The background for such antiinflammatory activity rests in in vitro and animal model studies. We report here our experience with curcumin therapy in 10 patients with inflammatory bowel disease.

\section{MATERIALS AND METHODS}

Five consecutive patients with ulcerative proctitis or proctosigmoiditis who agreed to participate in this study were entered (Table 1). There were three women and two men, aged 28

Manuscript received March 21, 2004; accepted August 10, 2004.

From *St. Luke's Roosevelt Hospital Center, Columbia University and Strang Cancer Center Research Laboratory, New York, New York, and $\dagger$ Long Island Clinical Research Associates, Great Neck, New York, USA.

Address for reprint requests: Peter R. Holt, MD,15 West 81 Street, New York, New York 10024, USA; pholt@ chpnet.org. to 54 years, who had complained of proctitis symptoms for 1 to 32 years. All had been previously treated with 5-aminosalicyclic acid (5ASA) compounds by mouth and/or rectum, three had received corticosteroid therapy at some time, and one subject was taking prednisone, $10 \mathrm{mg}$ per day, at study entry.

They were treated with $550 \mathrm{mg}$ of curcumin (DFM 100; 99.5\% pure $^{1}$ ) twice daily for $1 \mathrm{month}$ and then $550 \mathrm{mg}$ three times daily for another month. All had blood taken for hematologic and biochemical analysis and for indexes of inflammation (sedimentation rate and C-reactive protein [CRP]) and had sigmoidoscopies and biopsies both at baseline and 2 months later when the study ended.

Symptoms were assessed by a standard questionnaire at the start and conclusion of the study and by a daily symptom dairy. The endoscopic evaluation was not blinded since the investigator was aware of the timing of the procedure, however, the biopsies were obtained and evaluated for the degree of inflammation without knowledge of their timing.

Five subjects, three men and two women, with an established diagnosis of Crohn's disease were entered in this pilot study to determine whether the addition of curcumin to existing treatments for Crohn's disease would result in a reduction of inflammation with the ability to reduce other concomitant antiinflammatory agents (Table 1 ). The subjects were treated with curcumin, $360 \mathrm{mg}$ (1 capsule) three times daily for 1 month and then $360 \mathrm{mg}$ ( 4 capsules) four times daily for the remaining 2 months. Crohn's Disease Activity Index (CDAI), CRP, erythrocyte sedimentation rate (ESR), complete blood counts, and liver and renal function studies were obtained in all patients. All patients signed a consent form and IRB permission was obtained for this study.

\footnotetext{
${ }^{1}$ Kindly provided by R. Kane Products, Pennsauken, New Jersey.
} 
Table 1. Data on Ulcerative Proctosigmoiditis and Crohn's Disease Patients

\begin{tabular}{|c|c|c|c|c|}
\hline Patient No. & Age/sex & Extent of disease & $\begin{array}{c}\text { Length of disease } \\
\text { history }(y r)\end{array}$ & $\begin{array}{l}\text { Medications at } \\
\text { study entry }\end{array}$ \\
\hline \multicolumn{5}{|c|}{ A. Ulcerative proctosigmoiditis } \\
\hline 1. RK & $52 / \mathrm{F}$ & Proctitis & 32 & $\begin{array}{l}\text { 5ASA suppositories } \\
\text { Sulfasalazine, } 2 \mathrm{~g} 1 \mathrm{~d}\end{array}$ \\
\hline 2. EJ & $30 / \mathrm{F}$ & Proctitis & 01 & $\begin{array}{l}\text { 5ASA enemas and } \\
\text { suppositories }\end{array}$ \\
\hline 3. PM & $28 / \mathrm{M}$ & Proctitis & 05 & 5ASA enemas \\
\hline 4. JM & 29/M & Proctitis & 07 & $\begin{array}{l}\text { Sulfasalazine, } 2 \mathrm{~g} 1 \mathrm{~d} \\
\text { 5ASA suppositories }\end{array}$ \\
\hline 5. RP & $54 / \mathrm{F}$ & Proctosigmoiditis & 06 & $\begin{array}{l}\text { Prednisone, } 10 \mathrm{mg} \\
\text { 5ASA and enemas } \\
\text { Azathiopine, } 100 \mathrm{mg}\end{array}$ \\
\hline \multicolumn{5}{|c|}{ B. Crohn's disease } \\
\hline 1. JD & $43 / \mathrm{M}$ & lleocolitis & 22 & $\begin{array}{l}\text { Colestid, 3/day } \\
\text { 6MP, } 75 \mathrm{mg}\end{array}$ \\
\hline 2. RK & $47 / \mathrm{M}$ & Crohn's colitis & 26 & 6MP, $75 \mathrm{mg}$ \\
\hline 3. $\mathrm{BE}$ & $65 / \mathrm{F}$ & lleocolitis & 11 & 6MP, $75 \mathrm{mg}$ \\
\hline 4. JR & $50 / \mathrm{M}$ & lleojejunal colitis & 23 & $\begin{array}{l}\text { Flagyl, } 500 \mathrm{mg} \\
\text { Budesonide, } 9 \mathrm{mg}\end{array}$ \\
\hline 5. JWP & $33 / \mathrm{F}$ & Ileitis & 22 & None \\
\hline
\end{tabular}

Note. 5ASA, 5-aminosalicylic acid; 6MP, 6-methylprednisone.

\section{RESULTS}

Overall, all five subjects with proctitis improved by the end of the study as judged by a global score $(P<0.02$; Table 2). The major changes found were in the number and quality of stools. Two subjects eliminated their prestudy 5ASA medications, two subjects reduced their medications (including termination of the prednisone therapy in one subject), and one continued taking 5ASA suppositories. In these patients with limited ulcerative colitis, serologic indexes of inflammation, sedimentation rate, and CRP returned to within normal limits at the conclusion of the study.

The CDAI scores for all completed subjects fell, with a mean reduction of 55 points; sedimentation rate fell as well, with a mean reduction of $10 \mathrm{~mm} / \mathrm{hr}$ (Table 3). CRP was reduced by a mean of $0.1 \mathrm{mg} / \mathrm{dl}$. There were no changes in indexes of liver or renal function. Visits oc- curred every month, at which the four completed subjects reported improvement in clinical symptoms as follows: more formed stools, less frequent bowel movements, and less abdominal pain and cramping. One subject reported decreased muscle soreness, commonly felt after his exercise routine. Of the five subjects, four successfully completed and one discontinued due to lack of treatment effect, with a slight worsening of fistula output.

\section{DISCUSSION}

Curcumin has a profound immunosuppressive effect via inhibition of IL-2 synthesis as well as IL-2 and mitogen activation of human leukocytes. This immunosuppressive effect may be mediated by $\mathrm{NF} \kappa \mathrm{B}$ inhibition (7).

Further support is offered by data indicating that curcumin effectively inhibited tumor necrosis factor $\alpha$ and

Table 2. EFfects of Curcumin Administration in Ulcerative Proctitis Patients

\begin{tabular}{lccccccccc}
\hline Subject No. & $\begin{array}{c}\text { General } \\
\text { well-being }\end{array}$ & $\begin{array}{c}\text { No. of } \\
\text { stools }\end{array}$ & $\begin{array}{c}\text { Stool } \\
\text { quality }\end{array}$ & $\begin{array}{c}\text { Stool } \\
\text { blood }\end{array}$ & $\begin{array}{c}\text { Abdominal } \\
\text { pain }\end{array}$ & $\begin{array}{c}\text { Rectal pain } \\
\text { urgency }\end{array}$ & Medication & Endoscopy & $\begin{array}{c}\text { Global } \\
\text { score }\end{array}$ \\
\hline 1. Before & 1 & $2-3$ & 2 & 1 & 0 & 1 & Eliminated & 3 & 11 \\
After & 0 & 1 & 0 & 1 & 0 & 0 & & 2 & 4 \\
2. Before & 1 & $4+$ & 1 & 3 & 0 & 2 & Unchanged & 2 & 13 \\
After & 0 & $2-3$ & 1 & 3 & 0 & 2 & & 2 & 11 \\
3. Before & 0 & $2-3$ & 1 & 0 & 0 & 0 & Eliminated & 0 & 4 \\
After & 0 & 1 & 0 & 0 & 0 & 0 & & 0 & 1 \\
4. Before & 1 & $4+$ & 2 & 3 & 1 & 1 & Reduced ++ & 3 & 15 \\
After & 1 & $2-3$ & 0 & 3 & 0 & 0 & & 1 & 8 \\
5. Before & & $4+$ & $1-2$ & 1 & 0 & 1 & Reduced & 1 & 9 \\
After & & $1-2$ & $1-2$ & 1 & 0 & 1 & & 1 & 7 \\
\hline
\end{tabular}

Note. Numbers represent semiquantitative scores ranging from 1 to 3 . The higher the score, the worse the status. 
TABLE 3. EFFECTS OF CURCUMIN ADMINISTRATION IN CROHN'S DISEASE PATIENTS

\begin{tabular}{|c|c|c|c|c|c|c|}
\hline \multirow[b]{2}{*}{ Subject No. } & \multicolumn{3}{|c|}{$C D A I$} & \multicolumn{3}{|c|}{ Sedimentation rate } \\
\hline & Index & Change & $\%$ change & Rate & Change & $\%$ change \\
\hline 1. Before & 225 & & & 23 & & \\
\hline After & 196 & -29 & -12.9 & 19 & -4 & -17.4 \\
\hline 2. Before & 253 & & & 11 & & \\
\hline After & 155 & -98 & -38.7 & 6 & -5 & -45.5 \\
\hline 3. Before & 250 & & & 24 & & \\
\hline After & 239 & -11 & -44 & 7 & -17 & -70.8 \\
\hline 4. Before & 302 & & & 42 & & \\
\hline After & 220 & -82 & -27.2 & 28 & -14 & -33.3 \\
\hline
\end{tabular}

Note. CDAI, Crohn's Disease Activity Index. Data for the four subjects who completed the study.

phorbol ester-induced binding of $\mathrm{NF} \kappa \mathrm{B}$ transcription factors to sites located on the GSTP1-1 (glutathione $S$-transferase P1-1) gene promoter. These results indicate that curcumin could thereby induce apoptosis by its ability to inhibit GSTP1-1 expression at the transcription level (8).

In animal colitis models, curcumin has been shown to attenuate or prevent DNB or trinitrobenzene sulfonic acidinduced colitis in mice by suppressing CD4(+) T-cell infiltration and $\mathrm{NH} \kappa \mathrm{B}$ activation as well as reducing $\mathrm{p} 38$ MAPX activity $(9,10)$. Based on these reports we have shown that curcumin appears to have reduced the inflammatory response in four of five ulcerative colitis patients and four of five Crohn's disease patients.

\section{Conclusion}

The results of this pilot study indicate that further studies are warranted. A larger scale, double-blind, placebocontrolled trial is indicated.

\section{REFERENCES}

1. Ammon HPT, Wahl M: Pharmacology of Curcuma longa. Planta Med 57:1-7, 1991

2. Satoskar RR, Shah SJ, Shenoy SG: Evaluation of anti-inflammatory property of curcumin (diferuloytmethane) in patients with postoperative inflammation. Int J Pharmacol Ther Toxicol 24:651-654, 1986

3. Surh YJ: Anti-tumor promoting potential of selected spice ingredients with antioxidative and anti-inflammatory activities: a short review. Food Chem Toxicol 40:1091-1097, 2002

4. Toda S, Miyase T, Aricht H, Tanizawa H, Takino Y: Natural antioxidant $\mathrm{HI}$ antioxidative components isolated from rhizome of curcuma longa. Chem Pharm Bull 33:1725-1728, 1985

5. Hanif R, Qiao L, Shiff SJ, Rigas B: Curcumin a natural plant phenolic food additive inhibits cell proliferation and induces ceil cycle changes in colon adenocarcinoma cell lines by prostaglandin-independent pathways. J Lab Clin Med 130:576-584, 1997

6. Plummer SM, Holloway KA, Manson MM, Munks RJ, Kaptein A, Farrow S, Howells L: Inhibition of cyclo-oxygenase 2 expression in colon cells by the chemopreventive agent curcumin involves inhibition of NF- $\kappa$ B activation via the NIK/IKK signaling complex. Oncogene 18:6013-6020, 1999

7. Ranjan D, Chen C, Johnston TO, Reddy KS, Khan TT, Nagabhushan M: Curcumin inhibits mitogen stimulated lymphocyte proliferation NF- $\kappa$ B activation and IL-2 signaling. J Surg Res 114:272, 2003

8. Duvoix A, Morceau F, Deihalle S, Schmitz M, Schnekenburger M, Galteau MM, Dicato M, Diederichet M: Induction of apoptosis by curcumin: mediation by giutathione $\mathrm{S}$ transferase P1-1 inhibition. Biochem Pharmacol 66:1475-1483, 2003

9. Salh B, Assi K, Templeman V, Parhar K, Owen D, GomezMunoz A, Jacobsen K: Curcumin attenuates DNB-induced murine colitis. Am J Physiol Gastrointest Liver Physiol 285:G235, 2003

10. Sugimoto K, Hanai H, Tozawa K, Aoshi T, Uchijima M, Nagata T, Koide Y: Curcumin prevents and ameliorates trinitrobenzene surfonic acide induced colitis in mice. Gastroenterology 123:19121922, 2002 